УДК 616.89-02:615::616.89-008.441.33

Для цитирования: Афанасьева Н.А., Березовская М.А., Коробицина Т.В., Пичугина Ю.А., Сергиенко Н.Н. Клиникодинамические особенности интоксикационных психозов, вызванных употреблением современных синтетических психоактивных веществ. Сибирский вестник психиатрии и наркологии. 2017; 3 (96): 78-83. https://doi.org/10.26617/1810-31112017-3(96)-78-83

\title{
Клинико-динамические особенности интоксикационных психозов, вызванных употреблением современных синтетических психоактивных веществ
}

\section{Афранасьева Н.А., Березовская М.А., Коробицина Т.В., Пичугина Ю.А., Сергиенко Н.Н.} Красноярский государственный медииинский университет имени проф. В.Ф. Войно-Ясенеикого 660022, г. Красноярск, ул. Партизана Железняка, д. 1

\section{PEЗЮME}

Цель: Анализ научных публикаций, посвященных современным аспектам этиологии, патогенеза, развития, клинических проявлений психотических состояний, развившихся в результате употребления современных синтетических психоактивных веществ (ПАВ). Результаты и обсуждение. Представлен анализ литературных и собственных данных по проблеме развития шизофреноформных психозов на фоне употребления новых синтетических ПАВ. Современная ситуация, связанная с употреблением ПАВ, сложившаяся в последние годы в мире и России, отличается выраженной цикличностью распространения наркотических средств. Проблема употребления наркотических средств и психотропных веществ в обществе характеризуется появлением и достаточно быстрым распространением новых синтетических ПАВ со своеобразными клиническими эффектами. Отмечаются не только схожесть клинической картины психотических расстройств, вызванных приемом современных синтетических психостимуляторов и каннабиноидов, но и особенности протекания относимых к интоксикационным психозов. Обосновывается необходимость выявления дифференциально-диагностических критериев психозов, требуемых для терапии нарушений, поскольку отсутствует параллелизм между воздействием ПАВ и динамикой психотического расстройства, что усложняет этиологическую диагностику психоза в практике психиатров.

Ключевые слова: интоксикационные психозы, психоактивные вещества, шизофреноформные психические расстройства.

\section{ВВЕДЕНИЕ}

Последние несколько лет в России в целом и Сибирском федеральном округе и Красноярском крае в частности отмечается заметное увеличение числа госпитализированных в наркологические стационары пациентов с психотическими осложнениями, развивающимися на фоне интоксикации современными синтетическими ПАВ. Так, по данным Новосибирского областного наркологического диспансе$\mathrm{pa}$, количество обращений с психотическими расстройствами, возникшими вследствие употребления наркотиков и ненаркотических ПАВ, в областные медицинские организации психиатрического и наркологического профиля возросло с 266 случаев в 2011 г. до 829 в 2013 г. [20].

Подобная ситуация складывается и в Красноярском крае. По данным Красноярского краевого наркологического диспансера, количество больных, пролеченных с психотическими расстройствами, возникшими вследствие употребления наркотиков, возросло с 2 случаев в 2011 г. до 577 в 2014 г. с некоторым снижением до 422 случаев в 2015 г. [1, 21]. По мнению некоторых исследователей, отмечается изменение поведения на фоне потребления ПАВ, а сами психоактивные вещества являются источником получения удовольствия и «решением» жизненно трудных ситуаций [19]. В связи с таким увеличением в последнее пятилетие популярности употребления новых ПАВ исследование этиологических, патогенетических и клинических аспектов интоксикационных психозов вновь приобрело особое значение $[2,4,5$,6, 16, 22, 25, 26, 37].

\section{АКТУАЛЬНОСТЬ}

Интерес ученых и практиков к действию новых генераций ПАВ прежде всего определяется тем, что наблюдается резкий рост употребления синтетических психостимуляторов и каннабиноидов [15, 33], которые, несмотря на разнообразие химического состава, большое количество сленговых названий и способов применения, дают сходный своеобразный клинический эффект и вызывают шизофреноподобные интоксикационные расстройства $[3,23,24,33$, $42,43]$. Более того, психотические расстройства неалкогольной этиологии всё чаще встречаются в практике врачей-психиатров $[10,14]$. Причем отмечается не только сложность терапии психических расстройств, но и проблематичность этиологической диагностики психоза в связи с сокрытием пациентами анамнестических данных и отсроченностью поступления больных на лечение в стационар.

Цель исследования. Проанализировать материалы научных публикаций, посвященных современным аспектам этиологии, патогенеза, развития, клинических проявлений психотических состояний, развившихся в результате употребления современных синтетических психоактивных веществ.

\section{РЕЗУЛЬТАТЫ И ОБСУЖДЕНИЕ}

Обзор научных публикаций, описывающих особенности действия и химического состава современных синтетических ПАВ [17, 25, 26, 31, 36], показал, что в состав употребляемых смесей в основном входят такие вещества, как синтетические каннабиноиды, пировалерон, диметилпировалерон, ме- 
тилон, смешанные в различных пропорциях с другими вспомогательными веществами.

Синтетические ПАВ в России реализуются, главным образом, в виде так называемых курительных смесей и солей для ванн. В некоторых публикациях имеются указания как на высокую токсичность, так и наркогенность синтетических ПАВ. Согласно данным, приводимым К. Tomiyama и $\mathrm{M}$. Funada [41], синтетические каннабиоиды существенно превосходят натуральный каннабиноид 9ТГК по биологической активности.

Отмечается, что новые синтетические ПАВ вызывают интоксикационные психозы как с тяжелыми психическими, вегетативно-сосудистыми, так и иными расстройствами. Их клиническая картина значительно отличается от привычной картины металкогольных психозов или классических реакций экзогенно-токсического типа [29]. Как правило, в клинике психических нарушений, вызванных употреблением новых синтетических психоактивных веществ, преобладают шизофреноформные расстройства, нарушения мышления, памяти, внимания на фоне тревожности и хронической депрессии $[3,8$, $16,26]$. По мнению Н.А. Бохана и других авторов, употребление современных синтетических наркотиков приводит к развитию острых психотических расстройств в связи с резким искажением мыслительного процесса $[4,5,6,17]$. Ряд нейропсихологических исследований, проведенных в странах Европы $[34,35]$, показал, что в клинической картине наблюдаются специфические расстройства памяти на фоне эмоционально-волевых изменений. Данные клинических наблюдений позволяют выдвинуть предположение о том, что психотические расстройства, возникающие на фоне потребления современных синтетических психоактивных веществ, являются следствием высокой токсикокинетической и психодинамической составляющих их действия.

По данным некоторых авторов, наряду с развитием психических расстройств у больных наблюдались и нарушения в работе других органов и систем в процессе жизнедеятельности [15, 33, 42]. Лица, употреблявшие «курительные смеси», отмечали у себя нарушение сна, раздражительность, вспыльчивость, повышенную потливость, тахикардию, диспептические расстройства. С достаточно высокой частотой $\mathrm{y}$ таких пациентов можно было наблюдать психомоторное возбуждение, страх, тревогу, агрессию к окружающим, слуховые и тактильные галлюцинации, сочетающиеся с идеями преследования, воздействия, уверенностью в подстроенности ситуации, склонность к бредовой интерпретации окружающей обстановки на фоне ясного сознания.

Такие проявления отличают эти болезненные состояния от обычных интоксикационных психозов и требуют дифференциальной диагностики с органическими и шизофреническими психозами [26, 30, $32,39,44]$. Другие исследователи [18, 41] обращают внимание на развитие у лиц, потреблявших современные синтетические ПАВ, нарушений познава- тельной деятельности (память, внимание, речь, гнозис, праксис, мышление и др.).

Авторы, анализирующие отдельные случаи болезни пациентов с психотическими расстройствами, развившимися при употреблении синтетических ПАВ [11], также подчеркивают особенности клинической картины рассматриваемых психозов. У большинства больных психопатологические феномены заключались в возникновении бессонницы, беспокойства, ажитации, бреда, суицидальных попыток и в нарушении социального поведения.

В клинической картине обсуждаемых психозов с высокой частотой отмечаются нарушения когнитивных функций, тревожность, панические атаки, суицидальные мысли, выраженные психотические феномены - зрительные и слуховые галлюцинации, деперсонализация, бред, повышенная агрессивность, суицидальные действия. Интоксикационные психозы, вызванные новыми синтетическими и психостимуляторами [9] и каннабиноидами [13], протекают с выраженными неврологическими (гипертонус мышц, мидриаз, нарушение равновесия и др.), сердечно-сосудистыми (тахи- и брадикардия, нарушения ритма сердца, развитие инфаркта миокарда), дыхательными (легочные инфильтраты, пневмопатия), пищеварительными (тошнота, рвота, повышение аппетита) нарушениями.

При этом психоз формируется как у людей с отягощенной наследственностью по психическим расстройствам, так и у лиц, уже имеющих психическое заболевание [22, 37, 38]. Некоторые авторы полагают, что новые синтетические ПАВ сами по себе обладают высоким непосредственным психотическим потенциалом. Вследствие этого новые синтетические ПАВ представляют опасность не только в связи с наркогенностью, но и как вещества, способные вызвать серьезные психические расстройства даже при кратковременном потреблении [22, 40]. В некоторых публикациях [17, 27] приводятся данные, свидетельствующие о наличии прямой зависимости развития шизофрении после употребления наркотиков.

Можно выделить еще одну особенность психотических расстройств, развивающихся на фоне употребления современных синтетических ПАВ. Психопатологические феномены могут сохраняться за рамками непосредственного действия ПАВ, что отличает подобные состояния от классических интоксикационных психозов. Это обусловлено быстрым выведением вещества и его метаболитов, обычно определяемых стандартными методами лабораторного обследования (газохроматография и массспектромия) [10].

«Классические» представители групп ПАВ, например, такие как алкоголь, амфетамины, опиаты, растительные каннабиноиды, отличаются длительным периодом нахождения в биологических жидкостях и достаточно высокой чувствительностью методов их определения [12]. Так, для алкоголя средний период определения составляет от 6 до 24 часов, 
для барбитуратов - до 21 дня, для опиоидов - от 2 до 4 дней, для растительных каннабиноидов - от 2-3 дней до 12 недель в зависимости от длительности потребления. В случае потребления новых синтетических ПАВ наблюдается отсутствие параллелизма между воздействием токсического вещества и динамикой психотического расстройства.

Период определения метилендиоксипировалерона и синтетических каннабиноидов в биологических средах с помощью газовой или жидкостной хроматографии масс-спектрометрии для подтверждения диагноза интоксикационного психоза гораздо короче. Авторы некоторых исследований подчеркивают, что для синтетических каннабиноидов он составляет всего несколько часов, а для производных пировалерона до суток [28]. При этом в наших наблюдениях встречались случаи, когда острые психотические переживания могут сохраняться от 2-3 дней до недели, а нарушения памяти, внимания, шизофреноформные бредовые расстройства имеют длительность до месяца и более.

\section{ЗАКЛЮЧЕНИЕ}

В целом можно отметить значительное увеличение количества психотических осложнений вследствие употребления современных синтетических ПАВ, способных вызвать психозы не только у наркозависимых пациентов, но и у людей, принимавших их эпизодически или даже однократно. Несмотря на то что нарушения носят интоксикационный характер, только часть из них можно отнести к классическим интоксикационным психозам, поскольку клиническая картина представлена в большинстве случаев шизофреноформными расстройствами, отмечается более длительное течение и возникают существенные проблемы с определением токсического вещества или его метаболитов в биологических жидкостях стандартными методами лабораторного обследования. Это требует новых диагностических подходов, в том числе в дифференциальной диагностике психозов, вызванных синтетическими психостимуляторами и каннабиноидами.

\section{КОНФЛИКТ ИНТЕРЕСОВ}

Авторы декларируют отсутствие явных и потенциальных конфликтов интересов в связи с публикацией данной статьи.

\section{ИСТОЧНИК ФИНАНСИРОВАНИЯ}

Авторы заявляют об отсутствии финансирования при проведении исследования.

\section{СООТВЕТСТВИЕ ПРИНЦИПАМ ЭТИКИ}

Работа соответствует этическим стандартам Хельсинской декларации ВМА (протокол заседания этического комитета ФГБОУ ВО «Красноярский государственный медицинский университет имени профессора В.Ф. Войно-Ясенецкого» № 2/6 от 25.02.2012).

\section{ЛИТЕРАТУРА}

1. Анализ деятельности стационара круглосуточного пребывания КГБУЗ «Красноярский краевой наркологический диспансер №1» за 2012-2014 годы. Архив КГБУЗ ККНД. 2015: 21.

2. Аштон С. Неблагоприятные эффекты каннабиса и каннабиноидов. Наркология. 2009; 9: 71-87.

3. Белявский А.Р. Острые отравления новыми синтетическими наркотиками психостимулирующего действия: Информационное письмо для врачей. Екатеринбург. 2011: 18.

4. Бохан Н.А., Мандель А.И., Артемьев И.А., Невидимова Т.И., Батухтина Е.И., Воеводин И.В., Аболонин А.Ф., Солонский А.В., Прокопьева В.Д., Тощакова В.А., Епимахова Е.В., Шушпанова Т.В. Клинико-патобиологические закономерности формирования и патоморфоза алкоголизма и наркоманий в социально-организованных популяциях. $\mathrm{Cu}$ бирский вестник психиатрии и наркологии. 2015; 3 (88): 5363.

5. Бохан Н.А., Селиванов Г.Ю. Клиническая типология психопатологических расстройств у потребителей синтетических каннабиноидов (спайсов). Сибирский вестник психиатрии и наркологии. 2015; 4 (89): 18-23.

6. Бохан Н.А., Селиванов Г.Ю., Блонский К.А. Характеристика абстинентного синдрома у лиц, страдающих зависимостью от употребления синтетических каннабиноидов (спайсов). Сибирский вестник психиатрии и наркологии. 2016; 4 (93): 45-50.

7. Брусин К.М., Уразаев Т.Х., Липин Г.И. Острые отравления синтетическими наркотиками психостимулирующего действия. Роль токсикологических центров в обеспечении химической безопасности на региональном уровне: Тез. научно-практ. конф. Уральского федерального округа по клинической токсикологии с международным участием (13-15 октября 2011 г., Екатеринбург) / под ред. В.Г. Сенцова. Екатеринбург: УГМА, 2011: 116-117.

8. Доклад Международного комитета по контролю над наркотиками за 2013 год. Международный комитет по контролю над наркотиками. Нью-Йорк, Организация Объединенных Наций, 2014: 128.

9. Жевелик О.Д., Работин Р.А., Судаков А.Ю. Ретроспективное исследование случаев острой интоксикации синтетическими аналогами наркотических веществ (дизайнерскими наркотиками) в БУ «Нижневартовская психоневрологическая больница». Здравоохранение Югры: опыт и инновации. 2016; 4: 36-44.

10. Значение специальных лабораторных исследований для оценки и лечения расстройств, вызванных употреблением психоактивных веществ. Advances in Psychiatric Treatment. 1999; 5: 180-191.

11. Зобнин Ю.В., Стадлер Е.М. Острые отравления синтетическими каннабиноидами («спайсами»). Сибирский медицинский журнал. 2014; 8: 130-134.

12. Итоги деятельности Федеральной службы Российской Федерации по контролю за оборотом наркотиков в первом полугодии 2015 г. Доступ из справочно-правовой системы: htpp://www.fskn.gov.ru/pages/main/prevent/3939/4052/index.shtml

13. Каклюгин Н.В. «Синтетическая» Россия: прогрессирующее самоубийство наркотизирующейся молодежи. Проблемы и перспективы. Медииина. 2014; 4: 1-27.

14. Каклюгин Н.В. Современные виды наркотических средств и психотропных препаратов и психосоциальные последствия их потребления. Психическое здоровье. 2014; 2: 73-99.

15. Каклюгин Н.В. Современные виды наркотических средств и психотропных веществ. Бюллетень «Нарком». 2014; 4 (48): 8.

16. Лундквист Т. Влияние употребления каннабиса на когнитивные способности: сравнение с употреблением стимуляторов и героина в сфере воздействия на внимание, память и исполнительные функции. Наркология. 2010; 6: 74-87.

17. Овчинников А.А., Патрикеева О.Н. Синтетические каннабиноиды: психотропные эффекты, побочные действия, риски употребления. Медицина и образование в Сибири. 2014; 3: 82.

18. Пичугина Ю.А., Березовская М.А., Коробицина Т.В. Анализ современной ситуации употребления психоактивных веществ. Сибирское медицинское обозрение. 2016; 1: 40-47.

19. Сафронов Г.А., Головко А.И. Синтетические каннабиноиды. Состояние проблемы. Наркология. 2012; 10: 97-110.

20. Стрельчук И.В. Интоксикационные психозы. М.: Медицина, 1970.

21. Тетенова Ю.Ю. и др. Особенности употребления психоактивных веществ среди пользователей русскоязычного сегмента сети Интернет. Вопросы наркологии. 2013; 2: 52-62.

22. Хорошилов Г.П., Худяков А.В. Интоксикационные психозы, связанные с употреблением современных психоактивных веществ. Практическая медииина. 2015; 5 (90): 7-10. 
23. Чухрова М.Г., Пронин С.В., Рыбальчук Н.В., Иванова В.Э Психические и психосоматические последствия потребления спайсов. Мир науки, культуры, образования. 2015; (50): 423-426.

24. Шизофрения и курение марихуаны: сходная картина поражения головного мозга. [Электронный ресурc]. URL: http://ncpz.ru/news/26

25. Anizan S., Concheiro M. Linear pharmacokinetics of 3,4methylenedioxypyrovalerone (MDPV) and its metabolites in the rat: relationship to pharmacodynamic effects. Addiction Biology. 2015; 21 (2): 339-347.

26. Beck O., Franzen L., Backberg M. Intoxications involving MDPV in Sweden during 2010-2014: Results from the STRIDA project. Clinical Toxicology. 2015; 53 (9): 865-873.

27. Beck O., Franzen L., Backberg M. Toxicity evaluation of pyrrolidinovalerophenone (-PVP): results from intoxication cases within the STRIDA project. Clinical Toxycology. 2016; 54 (7): 568-575.

28. Brett C., Ginsburg et al. Purity of Synthetic Cannabinoids Sold Online for Recreational Use. J. Anal Toxicol. 2012; 1 (36): 66-68.

29. Chiurchiu V., Maccarone M. Cannabinoid Signaling and Neuroinflammatory Diseases: A Melting pot for the Regulation of Brain Immune Responses. J. Neuroimmune Pharmacology. 2015; 10 (2): 268-280.

30. Every-Palmer S. Synthetic cannabinoid JWH-018 and psychosis: an explorative study. Drug and Alcohol Dependence. 2011; 117: 152-157.

31. Hurst D., Loeffler G., McLay R. Psychosis Associated With Synthetic Cannabinoid Agonists: A Case Series. American Jour nal of Psychiatry. 2011; 168: 1119.

32. Ilan A.B., Smith M.E., Gevins A. Effects of marijuana on neurophysiological signals of working and episodic memory. Psycho pharmacology (Berl.). 2004; 176: 214-222.

33. Klavz J., Gorenjak M., Marinsek M. Suicide attempt with a mix of synthetic cannabinoids and synthetic cathinones: Case report of non-fatal intoxication with AB-CHMINACA, AB FUBINACA, alpha-PHP, alpha-PVP and 4-CMC. Forensic Science International. 2015. T.65: 121-124.

34. Moore T.H., Zammit S., Lingford-Hughes A. Cannabis use and risk of psychotic or affective mental health outcomes: a systematic review. Lancet. 2007; 370 (9584): 319-328.

35. Müller-Vahl K.R., Emrich H.M. Cannabis and schizophrenia: towards a cannabinoid hypothesis of schizophrenia. Expert Rev. Neurother. 2008; 8 (7): 1037-1048.
36. Thornton S.L., Gerona R.R., Tomaszewski C.A. Psychosis from a bath salt product containing flephedrone and MDPV with serum, urine, and product quantification. J. Med. Toxicol. 2012 Sep; 8(3): 310-313. doi: 10.1007/s13181-012-0232-4.

37. Rahmani M., Paul S., Nguyen M.L. Treatment of refractory substance-induced psychosisin adolescent males with a genetic predisposition to mental illness. Int. $J$ of Adolescent Medicine and Health. 2014; 26 (2): 297-301.

38. Ren Y., Whittard J., Higuera-Matas A. Cannabidiol, a nonpsychotropic component of cannabis, inhibits cue-induced heroin seeking and normalizes discrete mesolimbic neuronal disturbances. J. Neurosci. 2009; 29 (47): 14764-14769.

39. Schwartz R.H., Gruenewald P.J., Kltzner M. Short-term memory impairment in cannabis-dependent adolescents. Am. J. Disord. Child. 1989; 143: 1214-1219.

40. Thornton S.L., Lo J., Clark R.F. Simultaneous detection of multiple designer drugs in serum, urine, and CSF in a patient with prolonged psychosis. Informa. 2012; 10: 1165-1168.

41. Tomiyama K., Funada M. Cytotoxicity of synthetic cannabinoids found in «Spice» products: the role of cannabinoid receptors and the caspase cascade in the NG 108-15 cell line. Toxicol. Lett. 2011; 207 (1): 12-17.

42. Tomiyama K., Funada M. Cytotoxicity of synthetic cannabinoids on primary neuronal cells of the forebrain: the involvement of cannabinoid CB1 receptors and apoptotic cell death. Toxicol. Appl. Pharmacol. 2014; 274 (1): 17-23.

43. Van der Veer N., Friday J. Persistent psychosis following the use of Spice. Schizophr. Res. 2011; 130 (1-3): 285-286.

44. Wagner F.A., Anthony J.C. From First Drug Use to Drug Dependence: Developmental Periods of Risk for Dependence upon Marijuana, Cocaine, and Alcohol. Neuropsychopharmacology. 2002; 26: 479-488.

45. Zimmermann U.S., Winkelmann P.R., Pilhatsch M., Nees J.A., Spanagel R., Schulz K. With drawal phenomena and dependence syndrome after the consumption of «spice gold». Dtsch Arztebl Int. 2009; 106: 464-467.

Поступила в редакцию 14.04.2017 Утверждена к печати 26.06.2017

Афанасьева Наталья Анатольевна, ассистент кафедры психиатрии и наркологии с курсом ПО

Березовская Марина Альбертовна, д.м.н., заведующий кафедрой психиатрии и наркологии с курсом ПО.

Коробицина Татьяна Валерьевна, д.м.н., профессор кафедры психиатрии и наркологии с курсом ПО.

Пичугина Юлия Анатольевна, к.м.н., доцент кафедры психиатрии и наркологии с курсом ПО.

Сергиенко Наталья Николаевна, ассистент кафедры психиатрии и наркологии с курсом ПО.

Березовская Марина Альбертовна, mberezovska@mail.ru

УДК 616.89-02:615::616.89-008.441.33

For citation: Afanasyeva N.A., Berezovskaya M.A., Korobitsina T.V., Pichugina Yu.A., Sergienko N.N. Clinical and dynamic features of intoxication psychoses caused by the use of modern synthetic psychoactive substances. Siberian Herald of Psychiatry and Addiction Psychiatry. 2017; 3 (96): 78-83. https://doi.org/10.26617/1810-3111-2017-3(96)-78-83

\section{Clinical and dynamic features of intoxication psychoses caused by the use of modern synthetic psychoactive substances}

\section{Afanasyeva N.A., Berezovskaya M.A., Korobitsina T.V., Pichugina Yu.A., Sergienko N.N.}

Krasnoyarsk State Medical University named after prof. V.F. Voino-Yasenetsky Partizan Zheleznyak Street 1, 660022, Krasnoyarsk, Russian Federation

\section{ABSTRACT}

Objective: to analyze scientific publications dedicated to modern aspects of etiology, pathogenesis, development, clinical manifestations of psychotic states developed as a result of use of modern synthetic psychoactive substances (PAS). Results and Discussion. The analysis of literature and own data on the problem of the development of schizophreniform psychoses against the background of the use of new synthetic psychoactive substances is presented. The current situation, connected with the use of various psychoactive substances, has developed in recent years in the world and in Russia and is characterized by a pronounced cyclic distribution of narcotic drugs. The problem of the use of narcotic drugs and psychotropic substances in society is characterized by the appearance and rather rapid spread of new synthetic psychoactive substances with peculiar clinical effects. Not only similarity of the clinical picture of psychotic disorders caused by the use of modern synthetic psychostimulants and cannabinoids is noted, but also the peculiarities of the course of these psychotic-related 
ones. The necessity of revealing the differential-diagnostic criteria of psychoses required for the treatment of violations is substantiated, since there is no parallel between the influence of the psychoactive substance and the dynamics of the psychotic disorder, which complicates the etiological diagnosis of psychosis in the practice of psychiatrists.

\section{Keywords: intoxication psychosis, psychoactive substances, schizophreniform mental disorders.}

\section{REFERENCES}

1. Analiz deyatel'nosti stacionara kruglosutochnogo prebyvaniya KGBUZ «Krasnoyarskij kraevoj narkologicheskij dispanser №1» za 2012-2014 gody. Arhiv KGBUZ KKND [Analysis of the activities of a twenty-four-hour service of the Krasnoyarsk Krai Narcological Dispensary no. 1 for 2012-2014. Archive data]. 2015 (in Russian).

2. Ashton S. Neblagopriyatnye ehffekty kannabisa i kannabinoidov [Adverse effects of cannabis and cannabinoids]. Narkologiya Narcology. 2009; 9: 71-87 (in Russian).

3. Belyavskij A.R. Ostrye otravleniya novymi sinteticheskimi narkotikami psihostimuliruyushchego dejstviya, Informacionnoe pis'mo dlya vrachej [Acute intoxication of novel synthetic drugs of psychostimulant action. Circular for doctors]. Yekaterinburg. 2011: 18 (in Russian).

4. Bokhan N.A., Mandel A.I., Artemyev I.A., Nevidimova T.I., Batukhtina E.I., Voevodin I.V., Abolonin A.F., Solonsky A.V., Prokopieva V.D., Toshchakova V.A., Epimakhova E.V., Shushpanova T.V. Kliniko-patobiologicheskie zakonomernosti formirovaniya i patomorfoza alkogolizma i narkomaniy v sotsial'noorganizovannykh populyatsiyakh [Clinical-pathobiological regularities of alcoholism and drug addictions formation and pathomorphosis in socially organised populations]. Sibirskiy vestnik psikhiatrii i narkologii - Siberian Herald of Psychiatry and Addiction Psychiatry. 2015; 3 (88): 53-63 (in Russian).

5. Bokhan N.A., Selivanov G.Yu. Klinicheskaya tipologiya psihopatologicheskih rasstrojstv u potrebitelej sinteticheskih kannabinoidov (spajsov) [Clinical typology of psychopathological disorders in users of synthetic cannabinoids (spice)]. Sibirskiy vestnik psikhiatrii i narkologii - Siberian Herald of Psychiatry and Addiction Psychiatry. 2015; 4 (89): 18-23 (in Russian).

6. Bokhan N.A., Selivanov G.YU., Blonsky K.A. Harakteristika abstinentnogo sindroma u lic, stradayushchih zavisimost'yu ot upotrebleniya sinteticheskih kannabinoidov (spajsov) [Characteristics of withdrawal symptoms in people addicted to the use of synthetic cannabinoids ("spice")]. Sibirskiy vestnik psikhiatrii i narkologii - Siberian Herald of Psychiatry and Addiction Psychiatry. 2016; 4 (93): 45-50 (in Russian).

7. Brusin K.M., Urazaev T.H., Lipin G.I. Ostrye otravleniya sinteticheskimi narkotikami psihostimuliruyushchego dejstviya. Rol' toksikologicheskih centrov v obespechenii himicheskoj bezopasnosti na regional'nom urovne: Tez. nauch.-prakt. konf. Ural'skogo federal'nogo okruga po klinicheskoj toksikologii s mezhdunarodnym uchastiem (13-15 oktyabrya 2011 g., Ekaterinburg) [Acute intoxications with synthetic drugs of psychostimulant action. Role of detoxification centers in provision of chemical security at national level. Abstracts of the ScientificPractical Conference of the Ural Federal Okrug on clinical toxicology with international participation (13-15 October, 2011, Yekaterinburg]. V.G. Sentsov, ed. Yekaterinburg : UGMA, 2011: 116-117 (in Russian).

8. Doklad Mezhdunarodnogo komiteta po kontrolyu nad narkotikami za 2013 god. Mezhdunarodnyj komitet po kontrolyu nad narkotikami. N'yu-Jork, Organizaciya Ob'edinennyh Nacij [Report of the International Committee for Control of Drugs for 2013. New York, UNO]. 2014: 128 (in Russian).

9. Zhevelik O.D., Rabotin R.A., Sudakov A.Yu. Retrospektivnoe issledovanie sluchaev ostroj intoksikacii sinteticheskimi analogami narkoticheskih veshchestv (dizajnerskimi narkotikami) v BU «Nizhnevartovskaya psihonevrologicheskaya bol'nica» [Retrospective study analysis of cases of acute intoxication with synthetic analogs of narcotic substances (designer drugs) in BI "Nizhnevartovsk Psychoneurological Hospital"]. Zdravoohranenie Yugry: opyt i innovacii - Healthcare of Yugra: Experience and innovations. 2016; 4: 36-44 (in Russian).

10. Znachenie special'nyh laboratornyh issledovanij dlya ocenki i lecheniya rasstrojstv, vyzvannyh upotrebleniem psihoaktivnyh veshchestv [Significance of special laboratory investigations for evaluation and therapy of disorders due to use of psychoactive substances]. Advances in Psychiatric Treatment. 1999; 5: 180191.(in Russian).

11. Zobnin Yu.V., Stadler E.M. Ostrye otravleniya sinteticheskimi kannabinoidami («spajsami») [Acute intoxications with synthetic cannabinoids ("spice")]. Sibirskij medicinskij zhurnal - Siberian Medical Journal. 2014; 8: 130-134 (in Russian).

12. Itogi deyatel'nosti Federal'noj sluzhby Rossijskoj Federacii po kontrolyu za oborotom narkotikov v pervom polugodii $2015 \mathrm{~g}$ [Results of activities of the Federal Service of the Russian Federation on the control of drug trafficking in the first half of the year 2015]. Access from inquiry-legal system: htpp://www.fskn.gov.ru/ pages/main/prevent/ 3939/4052/index.shtml (in Russian).

13. Kaklyugin N.V. «Sinteticheskaya» Rossiya: progressiruyushchee samoubijstvo narkotiziruyushchejsya molodezhi. Problemy i perspektivy ["Syntetic Russia": Suicide of drug-abusing youth in progress. Problems and prospects]. Medicina - Medicine. 2014; 4: 1-27 (in Russian).

14. Kaklyugin N.V. Sovremennye vidy narkoticheskih sredstv i psihotropnyh preparatov i psihosocial'nye posledstviya ih potrebleniya [Modern types of drugs and psychotropic substances and psychosocial consequences of their abuse. Message 1. Natural and synthetic cannabinoids]. Psihicheskoe zdorov'e - Mental Health. 2014; 2: 73-99 (in Russian).

15. Kaklyugin N.V. Sovremennye vidy narkoticheskih sredstv i psihotropnyh veshchestv [Modern kinds of narcotic agents and psychotropic substances]. Byulleten' «Narkom»- Bulletin "Narcom”. 2014; 4 (48): 8 (in Russian).

16. Lundkvist T. Vliyanie upotrebleniya kannabisa na kognitivnye sposobnosti: sravnenie s upotrebleniem stimulyatorov i geroina $\mathrm{v}$ sfere vozdejstviya na vnimanie, pamyat' i ispolnitel'nye funkcii [Ccognitive consequences of cannabis use: comparison with abuse of stimulants and heroin with regard to attention, memory and executive functions]. Narkologiya - Narcology. 2010; 6: 74-87 (in Russian).

17. Ovchinnikov A.A., Patrikeeva O.N. Sinteticheskie kannabinoidy: psihotropnye ehffekty, pobochnye dejstviya, riski upotrebleniya [Synthetic cannabinoids: psychotropic effects, side effects, risks of use]. Medicina i obrazovanie v Sibiri - Medicine and Education in Siberia. 2014; $3: 82$ (in Russian).

18. Pichugina Yu.A., Berezovskaya M.A., Korobicina T.V. Analiz sovremennoj situacii upotrebleniya psihoaktivnyh veshchestv [Analysis of current situation of psychoactive substance use]. Sibirskoe medicinskoe obozrenie - Siberian Medical Review. 2016; 1: 40-47 (in Russian).

19. Safronov G.A., Golovko A.I. Sinteticheskie kannabinoidy. Sostoyanie problemy [Synthetic cannabinoids. State-of-the-art of the problem]. Narkologiya - Narcology. 2012; 10: 97-110 (in Russian).

20. Strel'chuk I.V. Intoksikacionnye psihozy: monografiya [Intoxication psychoses: monograph]. M.: Medicina, 1970 (in Russian).

21. Tetenova Yu.Yu. i dr. Osobennosti upotrebleniya psihoaktivnyh veshchestv sredi pol'zovatelej russkoyazychnogo segmenta seti Internet [Substance abuse trends among Russian-speaking internet users in 2011]. Voprosy narkologii - Journal of Addiction Problems. 2013; 2: 52-62 (in Russian).

22. Horoshilov G.P., Hudyakov A.V. Intoksikacionnye psihozy, svyazannye s upotrebleniem sovremennyh psihoaktivnyh veshchestv [Induced psychotic disorders associated with modern psychoactive substances usage]. Prakticheskaya medicina Practical Medicine. 2015; 5 (90): 7-10 (in Russian).

23. Chukhrova M.G., Pronin S.V., Rybal'chuk N.V., Ivanova V.E. Psihicheskie i psihosomaticheskie posledstviya potrebleniya spajsov [Psychological and psychosomatic effects of consumption of spices]. Mir nauki, kul'tury, obrazovaniya - World of Science, Culture, Education. 2015; 1 (50): 423-426 (in Russian).

24. Shizofreniya i kurenie marihuany: skhodnaya kartina porazheniya golovnogo mozga [Schizophrenia and smoking of marihuana: similar picture of brain impairment]. [Elektronnyj resurs]. URL: http://ncpz.ru/news/26 (in Russian). 
25. Anizan S., Concheiro M. Linear pharmacokinetics of 3,4methylenedioxypyrovalerone (MDPV) and its metabolites in the rat: relationship to pharmacodynamic effects. Addiction Biology. 2015; 21 (2): 339-347.

26. Beck O., Franzen L., Backberg M. Intoxications involving MDPV in Sweden during 2010-2014: Results from the STRIDA project. Clinical Toxicology. 2015; 53 (9): 865-873.

27. Beck O., Franzen L., Backberg M. Toxicity evaluation of pyrrolidinovalerophenone (-PVP): results from intoxication cases within the STRIDA project. Clinical Toxycology. 2016; 54 (7): $568-575$

28. Brett C., Ginsburg et al. Purity of Synthetic Cannabinoids Sold Online for Recreational Use. J. Anal Toxicol. 2012; 1 (36): 66-68.

29. Chiurchiu V., Maccarone M. Cannabinoid Signaling and Neuroinflammatory Diseases: A Melting pot for the Regulation of Brain Immune Responses. J. Neuroimmune Pharmacology. 2015; 10 (2): 268-280.

30. Every-Palmer S. Synthetic cannabinoid JWH-018 and psychosis: an explorative study. Drug and Alcohol Dependence. 2011; 117 152-157.

31. Hurst D., Loeffler G., McLay R. Psychosis Associated With Synthetic Cannabinoid Agonists: A Case Series. American Journal of Psychiatry. 2011; 168: 1119.

32. Ilan A.B., Smith M.E., Gevins A. Effects of marijuana on neurophysiological signals of working and episodic memory. Psychopharmacology (Berl.). 2004; 176: 214-222.

33. Klavz J., Gorenjak M., Marinsek M. Suicide attempt with a mix of synthetic cannabinoids and synthetic cathinones: Case report of non-fatal intoxication with AB-CHMINACA, AB FUBINACA, alpha-PHP, alpha-PVP and 4-CMC. Forensic Science International. 2015. T.65: 121-124.

34. Moore T.H., Zammit S., Lingford-Hughes A. Cannabis use and risk of psychotic or affective mental health outcomes: a systematic review. Lancet. 2007; 370 (9584): 319-328

35. Müller-Vahl K.R., Emrich H.M. Cannabis and schizophrenia: towards a cannabinoid hypothesis of schizophrenia. Expert Rev. Neurother. 2008; 8 (7): 1037-1048.

36. Thornton S.L., Gerona R.R., Tomaszewski C.A. Psychosis from a bath salt product containing flephedrone and MDPV with se- rum, urine, and product quantification. J. Med. Toxicol. 2012; Sep; 8(3): 310-313. doi: 10.1007/s13181-012-0232-4.

37. Rahmani M., Paul S., Nguyen M.L. Treatment of refractory substance-induced psychosisin adolescent males with a genetic predisposition to mental illness. Int. J of Adolescent Medicine and Health. 2014; 26 (2): 297-301.

38. Ren Y., Whittard J., Higuera-Matas A. Cannabidiol, a nonpsychotropic component of cannabis, inhibits cue-induced heroin seeking and normalizes discrete mesolimbic neuronal disturbances. J. Neurosci. 2009; 29 (47): 14764-14769.

39. Schwartz R.H., Gruenewald P.J., Kltzner M. Short-term memory impairment in cannabis-dependent adolescents. Am. J. Disord. Child. 1989; 143: 1214-1219.

40. Thornton S.L., Lo J., Clark R.F. Simultaneous detection of multiple designer drugs in serum, urine, and CSF in a patient with prolonged psychosis. Informa. 2012; 10: 1165-1168.

41. Tomiyama K., Funada M. Cytotoxicity of synthetic cannabinoids found in «Spice» products: the role of cannabinoid receptors and the caspase cascade in the NG 108-15 cell line. Toxicol. Lett. 2011; 207 (1): 12-17.

42. Tomiyama K., Funada M. Cytotoxicity of synthetic cannabinoids on primary neuronal cells of the forebrain: the involvement of cannabinoid CB1 receptors and apoptotic cell death Toxicol. Appl. Pharmacol. 2014; 274 (1): 17-23.

43. Van der Veer N., Friday J. Persistent psychosis following the use of Spice. Schizophr. Res. 2011; 130 (1-3): 285-286.

44. Wagner F.A., Anthony J.C. From First Drug Use to Drug Dependence: Developmental Periods of Risk for Dependence upon Marijuana, Cocaine, and Alcohol. Neuropsychopharmacology. 2002; 26: 479-488.

45. Zimmermann U.S., Winkelmann P.R., Pilhatsch M., Nees J.A., Spanagel R., Schulz K. With drawal phenomena and dependence syndrome after the consumption of «spice gold». Dtsch Arztebl Int. 2009; 106: 464-467.

Received April 14.2017 Accepted June 26.2017

Afanasyeva Natalia A., assistant of the Department of Psychiatry and Narcology with a course Postgraduate Education, Krasnoyarsk State Medical University named after prof. V.F. Voino-Yasenetsky, Krasnoyarsk, Russian Federation.

Berezovskaya Marina A., MD, head of the Department of Psychiatry and Narcology with a course Postgraduate Education, Krasnoyarsk State Medical University named after prof. V.F. Voino-Yasenetsky, Krasnoyarsk, Russian Federation.

Korobitsina Tatyana V., MD., professor of the Department of Psychiatry and Narcology with a course Postgraduate Education, Krasnoyarsk State Medical University named after prof. V.F. Voino-Yasenetsky, Krasnoyarsk, Russian Federation.

Pichugina Julia A., PhD., senior lecturer of the Department of Psychiatry and Narcology with a course Postgraduate Education, Krasnoyarsk State Medical University named after prof. V.F. Voino-Yasenetsky, Krasnoyarsk, Russian Federation.

Sergienko Natalia N., assistant of the Department of Psychiatry and Narcology with a course Postgraduate Education, Krasnoyarsk State Medical University named after prof. V.F. Voino-Yasenetsky, Krasnoyarsk, Russian Federation. 